\title{
PENINGKATAN HASIL BELAJAR MENGGUNAKAN METODE DEMONSTRASI PADA BIDANG STUDI AL-QUR'AN HADITS MI
}

\author{
Ali Imron \\ Dosen FAI Unwahas Semarang \\ aliimron@gmail.com
}

\begin{abstract}
Abstrak
Madrasah merupakan institusi pendidikan bercorak ke-Islaman, dari sisi budaya posisi ini sangat strategis sebab karakter ke-Islaman dapat dibangun secara moderat sejak dini. Secara politis, eksistensi madrasah dapat dijadikan sebagai parameter kekuatan Islam. Madrasah memiliki kontribusi penting dalam keikutsertaannya mencerdaskan kehidupan bangsa. Banyaknya jumlah Madrasah di Indonesia serta jumlah peserta didiknya pada tiap Madrasah, menjadikan lembaga ini layak diperhitungkan dalam pembangunan bangsa di bidang pendidikan dan moral. Perbaikan secara terus menerus dilakukan terhadap madrasah, baik dari segi manajemen, akademik (kurikulum) maupun fasilitas, hingga menjadikan madrasah keluar dari kesan tradisional dan kolot. Madrasah Ibtidaiyah (MI) setingkat Sekolah Dasar (SD), sebagai sebuah institusi di tingkat dasar MI memiliki peran yang cukup vital karena merupakan institusi pendidikan Islam di tingkat dasar yang berperan ganda. MI tidak hanya mengenalkan ilmu pengetahuan umum, namun juga melakukan transfer nilai-nilai keagamaan, sehingga diperlukan pengelolaan yang baik dan profesional. Salah satu bidang keagamaan yang disampaikan di MI adalah bidang studi Al-Qur'an Hadits, dengan tujuan memberikan kemampuan dasar membaca, menulis, membiasakan, dan menggemari membaca Al-Qur'an dan Hadits. Membina dan membimbing perilaku peserta didik dengan berpedoman pada isi kandungan ayat Al-Qur'an dan Hadits. Tujuan sebagai hasil belajar tersebut membutuhkan metode untuk mencapainya, dan di antara metode yang digunakan adalah metode demonstrasi.
\end{abstract}

Kata kunci: hasil belajar, metode demonstrasi, Al-Qur'an Hadits MI

\begin{abstract}
Madrasah is an Islamic educational institution. From culture side, this positionis very strategic because the Islamic characters can be built moderately early. Politically, the existence of madrasah can be used as parameter of Islamic power. Madrasah has an important contribution in educating the nation. A large number of Madrasah in Indonesia as well as the number of learners in each Madrasah, making this institution to be
\end{abstract}


reckoned in the national development in education and moral. Continual improvements always do to madrasah, both in management, academic (curriculum) and facilities. Those make madrasah is not like traditional and out of date. Islamic Elementary School (MI) as level as Elementary School (SD), is an institution on basic level. MI has a vital role because is an Islamic education institution on basic level which has dual roles. MI not only introduces the general science, but also to transfer religious values, so needed good management and professional. One of religious field delivered by MI is Al-Qur'an Hadits study. It goals to give basic skills of reading, writing, adapt, and fond of reading Al-Qur'an and Hadits. Nurture and guide learners' behavoiur based on the content of Al-Qur'an and Hadits. The aim of learning result need some methods to achieve it, and among those methods used is demonstration method.

Keywords: Learning Result, Demonstration Method, Al-Quran and Hadits for $M I$

\section{A. Pendahuluan}

Fungsi pendidikan bagi guru yang utama adalah memimpin anak-anak membawa ke arah tujuan yang jelas. Guru sebagai orang tua juga harus menjadi model atau suri tauladan bagi anak-anak. Anak mendapatkan rasa keamanan dengan adanya model dan rela menerima petunjuk maupun teguran bahkan hukuman. ${ }^{1}$

Pendidikan sekolah juga merupakan pendidikan yang diselenggarakan melalui prasarana yang dilembagakan. Lembaga pendidikan sekolah merupakan tempat menuntut ilmu kedua setelah keluarga. Proses belajar mengajar merupakan inti dari proses pendidikan secara keseluruhan dengan guru sebagai pemegang peran utama. Guru adalah orang yang memberikan ilmu pengetahuan kepada anak didik. ${ }^{2}$ Oleh karena itu, gurulah yang bertanggung jawab dalam melaksanakan pendidikan dalam arti memberikan bimbingan dan pengajaran kepada peserta didik.

Pembelajaran Al-Qur'an Hadits di MI ternyata tidak mudah. Adanya anggapan bahwa Al-Qur'an Hadits hanyalah pelajaran yang sekedar dibaca

1 Syaiful Bahri Jamaroh, Guru dan Anak Didik dalam Interaksi Edukatif, Jakarta: Rineka Cipta, 2000, hlm. 5.

2 Syaiful Bahri Jamaroh, Guru dan Anak Didik ... hlm. 31. 
dan tidak harus dihafalkan maupun dipahami, serta pelajaran ini tidak termasuk pelajaran yang menentukan peserta didik tergolong statis maupun kurang berprestasi. Hal ini jika dibiarkan berlarut-larut tentunya akan sangat membahayakan akhlaq dan aqidah generasi muda. Pengaruh yang saat ini bisa kita lihat adalah adanya penurunan kesadaran beribadah peserta didik dalam kehidupan sehari-hari.

Berdasarkan masalah yang dialami peserta didik MI, penulis berasumsi bahwa untuk menarik minat belajar peserta didik terhadap pelajaran Al-Qur'an Hadits adalah dengan menciptakan suasana senang dalam pembelajaran Al-Qur'an Hadits. Salah satu cara yang dapat dilakukan guru dalam menciptakan susasana menyenangkan adalah dengan memilih dan menggunakan metode pembelajaran yang tepat. Pemilihan metode yang kurang tepat dapat menimbulkan kebosanan, gagal paham, dan akhirnya menurunkan motivasi belajar yang berakibat pada hasil belajar peserta didik yang rendah.

Metode adalah "suatu cara atau siasat penyampaian bahan pengajaran tertentu dari suatu mata pelajaran, agar peserta didik dapat mengetahui, memahami, mempergunakan, dan menguasai bahan pengajaran. Proses belajar mengajar terjadi atas interaksi dua arah antara pengajar dan peserta didik. Ada beberapa metode yang dikenal dalam pengajaran, misalnya metode ceramah, metode demonstrasi, metode pemberian tugas, metode eksperimen, metode tanya jawab, dan sebagainya. Pemilihan metode yang tepat merupakan landasan keberhasilan suatu lembaga pendidikan, karena seorang guru dapat menentukan output serta dapat memberikan pengalaman belajar yang menyenangkan kepada peserta didik. Oleh sebab itu, untuk dapat menciptakan suasana belajar yang kreatif dalam mata pelajaran AlQur'an Hadits, guru dapat memilih metode demonstrasi, karena dalam pelajaran ini ada materi yang dapat diterapkan atau dipraktekkan, seperti menghafal Al-Qur'an dalam surat pendek pilihan. 


\section{B. Landasan Teori}

\section{Belajar dan Pembelajaran}

\section{a. Pengertian Belajar dan Pembelajaran}

\section{1) Pengertian Belajar}

Menurut Muhibbin Syah, belajar adalah kegiatan yang berproses dan merupakan unsur yang sangat fundamental dalam setiap penyelenggaraan jenis dan jenjang pendidikan. ${ }^{3}$ Sholeh Abdul Azis dan Abdul Azis Abdul Majid menjelaskan tentang definisi belajar:

$$
\text { ان التعلم هو تغيير فى ذهن المتعلم يطر أ على خبرة سابقة فيحث فيها تغييرا جديد|4 }
$$

Sesungguhnya belajar adalah merubah pemahaman peserta didik dari pengalaman yang lama, maka di dalamnya membahas perubahan yang baru.

Arno F. Witting mengartikan belajar adalah "learning can be defined as any relatively permanent change in an organism behavioral repertoire that occurs as a result of experience".5

Menurut Skinner, belajar merupakan suatu proses adaptasi atau penyesuaian atau tingkah laku yang berlangsung secara progresif. Proses adaptasi tersebut akan mendatangkan hasil yang optimal apabila ia diberi penguat. ${ }^{6}$

Persepsi yang lain diberikan oleh Devista dan Thompson dalam bukunya Nana Syaodih Sukmadinata, yang mengartikan belajar sebagai perubahan tingkah laku yang relatif menetap sebagai hasil dari pengalaman.7 Slameto mendefinisikan belajar sebagai suatu proses perubahan, yaitu perubahan tingkah laku sebagai hasil dari

3 Muhibbin Syah, Psikologi Pendidikan dengan Pendekatan Baru, Bandung: Rosdakarya, 2003, hlm. 89.

4 Sholeh Abdul Azis, At Tarbiyah wa Turuqut At Tadriis, Mesir: Darul Ma'arif, tt, hlm. 2.

5 Arno F. Witting, Psycology of Learning, New York: Mc Graw Hill, 1981, hlm. 2.

6 Muhibbin Syah, Psikologi Pendidikan ... hlm. 90.

7 Nana Syaodih Sukmadinata, Landasan Psikologi Proses Pendidikan, Bandung: Rosdakarya, 2003, hlm. 156. 
interaksi dengan lingkungannya dalam memenuhi kebutuhan hidupnya. 8

Berdasarkan beberapa pengertian belajar menurut para ahli diatas, dapat disimpulkan bahwa belajar diartikan sebagai suatu proses tingkah laku yang berlangsung secara progresif yang diperoleh dari interaksi dan pengalaman, yang mana pengalaman itu akan lebih bermakna jika diberi penguat dengan penguat yang lebih cepat.

\section{2) Pengertian Pembelajaran}

Pembelajaran pada hakikatnya merupakan proses komunikasi antara peserta didik dengan pendidik, serta antar peserta didik dalam rangka perubahan sikap. Oleh sebab itu, baik secara konseptual maupun operasional konsep-konsep komunikasi dan perubahan sikap akan selalu melekat pada pembelajaran. ${ }^{9}$

Pembelajaran adalah proses interaksi peserta didik dengan pendidik dan sumber belajar pada suatu lingkungan belajar. ${ }^{10}$ Berdasarkan pendapat para ahli tentang pengertian pembelajaran, maka dapat disimpulkan bahwa pembelajaran adalah proses interaksi peserta didik dengan pendidik untuk mengubah sikap peserta didik supaya menjadi lebih baik, serta memfalisitasi peserta didik dengan cara melengkapi sarana prasarana yang saling mempengaruhi untuk mencapai tujuan pembelajaran.

\section{b. Ciri-ciri Belajar dan Pembelajaran}

\section{1) Ciri-Ciri Belajar} hlm. 2 .

8 Slameto, Belajar dan Faktor yang Mempengaruhinya, Jakarta: Rineka Cipta, 1995, $15-16$

9 Syaiful Bahri Djamaroh, Psikologi Belajar, Jakarta: Rineka Cipta, 2008, cet. II, hlm.

10 Asep Jihad, Abdul Haris, Evaluasi Pembelajaran, Yogyakarta: Multi Presindo, 2008, hlm. 11. 
Jika hakikat belajar adalah perubahan tingkah laku, maka ada beberapa perubahan tertentu yang dimasukkan ke dalam ciri-ciri belajar antara lain :

a) Perubahan yang terjadi secara sadar

Individu yang belajar akan menyadari terjadinya perubahan itu atau sekurang-kurangnya individu merasakan telah terjadi suatu perubahan dalam dirinya. Misalnya, ia menyadari bahwa pengetahuannya bertambah, kecakapannya bertambah, dan kebiasaannya bertambah.

b) Perubahan dalam belajar bersifat fungsional Sebagai hasil belajar, perubahan yang terjadi dalam diri individu berlangsung terus menurus dan tidak statis. Suatu perubahan yang terjadi akan menyebabkan perubahan berikutnya dan akan berguna bagi kehidupan ataupun proses belajar berikutnya. Misalnya, jika seseorang anak belajar menulis, maka ia akan mengalami perubahan dari tidak bisa menulis menjadi bisa menulis.

c) Perubahan dalam belajar bersifat positif dan aktif

Dalam perbuatan belajar, perubahan-perubahan itu selalu bertambah dan tertuju untuk memperoleh sesuatu yang lebih dari sebelumnya. Dengan demikian, makin banyak usaha belajar itu dilakukan, makin banyak dan makin baik perubahan yang diperoleh.

d) Perubahan dalam belajar bukan bersifat sementara Perubahan yang bersifat sementara (temporer) yang terjadi hanya beberapa saat saja, seperti berkeringat, keluar air mata, menangis dan lain sebagainya tidak dapat digolongkan sebagai perubahan dalam pengertian belajar.

e) Perubahan dalam belajar bertujuan atau terarah 
Ini berarti bahwa perubahan tingkah laku itu terjadi karena ada tujuan yang akan dicapai. Perubahan belajar terarah pada perubahan tingkah laku yang benar-benar disadari. Misalnya, seseorang yang belajar mengetik, sebelumnya sudah menetapkan apa yang mungkin dapat dicapai dengan belajar mengetik, atau tingkat kecakapan mana yang dicapainya.

f) Perubahan mencakup seluruh aspek tingkah laku

Perubahan yang diperoleh individu setelah melalui suatu proses belajar meliputi perubahan keseluruhan tingkah laku. ${ }^{11}$

\section{2) Ciri-Ciri Pembelajaran}

Ciri-ciri pembelajaran antara lain:

a) Rencana, ialah penataan ketenangan material dan prosedur yang merupakan unsur-unsur sistem pembelajaran dalam suatu rencana khusus.

b) Saling ketergantungan (Interpendence) antara unsur-unsur sistem pembelajaran yang serasi dalam suatu keseluruhan.

c) Tujuan yaitu sistem tujuan tertentu yang hendak dicapai. ${ }^{12}$

\section{c. Teori Belajar dan Pembelajaran}

\section{1) Teori Belajar}

Berikut dijabarkan tentang teori-teori belajar untuk memperjelas pengertian belajar diatas, yaitu:

a) Teori belajar Konstruktivis

Teori Konskruktivis merupakan teori yang berkembang dari kerja Piaget dan Vygotsky yang menjelaskan bahwa pesrta didik harus menemukan sendiri dan mentransformasi informasi kompleks,

11 Syaiful Bahri Djamaroh, Psikologi Belajar, Jakarta: Rineka Cipta, 2008, cet. II, hlm. 15-16.

12 Oemar Hamalik, Kurikulum dan Pembelajaran, Jakarta: Bumi Aksara, 2008, cet. VIII, hlm. 55-56 
mengecek informasi baru dengan aturan-aturan lama dan merevisinya apalagi aturan-aturan itu tidak sesuai lagi. ${ }^{13}$

b) Teori belajar bermakna David Ausabel

Teori belajar bermakna David Ausabel dijelaskan bahwa belajar merupakan suatu proses dikaitkannya informasi baru pada konsep-konsep relevan yang terdapat dalam struktur kognitif seseorang. ${ }^{14}$ Adapun ciri-ciri belajar adalah merupakan tindakan dan perilaku peserta didik yang kompleks sebagai tindakan, maka belajar hanya dialami oleh peserta didik sendiri. ${ }^{15}$

\section{2) Teori Pembelajaran}

Istilah belajar dan mengajar adalah dua peristiwa yang berbeda, tetapi terdapat hubungan yang erat dalam pelaksanaannya (pembelajaran), bahkan terjadi kaitan interaksi saling mempengaruhi dan saling menunjang satu sama lain. Adapun teori-teori pembelajaran meliputi: ${ }^{16}$

a) Pembelajaran adalah upaya mengorganisasi lingkungan untuk menciptakan kondisi belajar bagi peserta didik.

b) Pembelajaran adalah upaya mempersiapkan peserta didik untuk menjadi warga masyarakat yang baik.

c) Pembelajaran adalah suatu proses membantu peserta didik menghadapi kehidupan masyarakat sehari-hari.

\section{d. Faktor-faktor yang mempengaruhi Belajar}

Belajar sebagai proses atau aktivitas disyaratkan oleh banyak sekali faktor-faktor. Adapun faktor yang mempengaruhi belajar meliputi: 1) Faktor-faktor yang berasal dari luar diri pelajar, yang digolongkan menjadi dua golongan yaitu:

13 Triyanto, Model-Model Pembelajaran Inovatif Berorientasi Konstruktivis, Surabaya: Prestasi Pustaka, 2007, hlm. 13.

14 Triyanto, Model-Model Pembelajaran Inovatif ... hlm. 25.

15 Dimyati, Nudjrono, Belajar dan Pembelajaran, Jakarta: Rineka Cipta, 1999, cet.1, hlm. 7.

16 Oemar Hamalik, Kurikulum dan Pembelajaran, Jakarta: Bumi Aksara, 2008, cet. VIII, hlm. 57-64. 
a) Faktor-faktor non-sosial dalam belajar

Faktor-faktor ini tak terbilang jumlahnya, misalnya: keadaan udara, cuaca, waktu (pagi, siang, ataupun malam), tempat (letaknya, pergedungannya), alat-alat yang dipakai untuk belajar (seperti alat tulis menulis, buku-buku, alat-alat peraga, dan lain sebagainya).

b) Faktor-faktor sosial dalam belajar

Yang dimaksud dengan faktor-faktor sosial di sini adalah faktor manusia (sesama manusia), atau kehadiran orang atau orang-orang lain pada waktu seseorang sedang belajar. Ada juga faktor yang berasal dari dalam kelas misalnya, jika satu kelas peserta didik sedang mengerjakan ujian, lalu terdengar anak-anak lain bercakapcakap di samping kelas, maka peserta didik yang sedang mengerjakan ujian akan sangat terganggu. ${ }^{17}$

2) Faktor-faktor yang berasal dari dalam diri pelajar

a) Faktor-faktor fisiologis

Faktor-faktor fisiologis ini dapat dibedakan menjadi dua yaitu tonus jasmani pada umumnya dan keadaan fungsi-fungsi fisiologis tertentu. ${ }^{18}$

b) Keadaan tonus jasmani pada umumnya

Keadaan tonus jasmani pada umumnya dapat dikatakan melatarbelakangi aktivitas belajar, keadaan jasmani yang segar akan lain pengaruhnya dengan keadaan jasmani yang kurang segar, keadaan jasmani yang lelah lain pengaruhnya daripada yang tidak lelah.

c) Keadaan fungsi-fungsi jasmani tertentu terutama fungsi panca indera.

17 Sumadi Suryabrata, Psikologi Pendidikan, Jakarta: PT. Raja Grafindo Persada, 2001, cet. X, hlm. 233-234.

18 Sumadi Suryabrata, Psikologi ... hlm. 235 
Panca indera dapat dimisalkan sebagai pintu gerbang masuknya pengaruh ke dalam individu. Orang mengenal dunia sekitarnya dan belajar dengan mempergunakan panca inderanya.

d) Faktor-faktor psikologis dalam belajar Menurut Arden N. Frandsen dalam bukunya Sumadi Suryabrata mengatakan bahwa hal yang mendorong seseorang untuk belajar adalah sebagai berikut:

(1) Adanya sifat ingin tahu dan ingin menyelidiki dunia yang lebih luas.

(2) Adanya sifat yang kreatif yang ada pada manusia dan keinginan untuk selalu maju.

(3) Adanya keinginan untuk mendapatkan simpati dari orang tua, guru, dan teman-teman.

(4) Adanya keinginan untuk memperbaiki kegagalan yang lalu dengan usaha yang baru, baik dengan koperasi maupun dengan kompetensi.

(5) Adanya keinginan untuk mendapatkan rasa aman bila menguasai pelajaran.

(6) Adanya ganjaran atau hukuman sebagai hasil daripada belajar.

Sedangkan Moslow mengemukakan bahwa motif-motif untuk belajar itu adalah:

(1) Adanya kebutuhan fisik

(2) Adanya kebutuhan akan rasa aman, bebas dari kekhawatiran.

(3) Adanya kebutuhan untuk mendapat kehormatan dari masyarakat.

(4) Sesuai dengan sifat untuk mengemukakan atau mengetengahkan diri. ${ }^{19}$

\section{e. Hasil Belajar}

\section{1) Pengertian Hasil Belajar}

Menurut Abdurrahman, hasil belajar adalah kemampuan yang diperoleh anak setelah melalui kegiatan belajar. ${ }^{20}$ Hasil belajar pada hakikatnya merupakan kompetensi yang mencakup aspek

\footnotetext{
19 Sumadi Suryabrata, Psikologi ... hlm. 325-237.

${ }^{20}$ Asep Jihad, Abdul Haris, Evaluasi ... hlm. 14
} 
pengetahuan, keterampilan, sikap dan nilai-nilai yang diwujudkan dalam kebiasaan berpikir dan bertindak.

\section{2) Macam-macam Hasil Belajar}

Hasil belajar adalah kemampuan-kemampuan yang dimiliki peserta didik setelah menerima pengalaman belajar. Howard Kingsley membagi tiga macam hasil belajar, yakni: (a) keterampilan dan kebiasaan, (b) pengetahuan dan pengertian, serta (c) sikap dan citacita. Adapun Gagne membagi lima kategori hasil belajar peserta didik di sekolah, yakni informasi verbal, keterampilan intelektual, strategi kognitif, sikap, dan keterampilan motoris. ${ }^{21}$

Ciri-ciri hasil belajar yang dicapai peserta didik melalui proses belajar mengajar yang optimal adalah sebagai berikut:
a) Kepuasan dan kebanggaan yang dapat menumbuhkan motivasi belajar peserta didik.
b) Menambah keyakinan akan kemampuan diri
c) Kemantapan dan ketahanan hasil belajar
d) Hasil belajar yang diperoleh secara menyeluruh (komprehensif)
e) Kemampuan peserta didik untuk mengontrol atau menilai dan mengendalikan diri pada proses dan usaha belajar. ${ }^{22}$
Kemampuan pendidik (guru) dalam membimbing belajar peserta didik sangat dituntut untuk dapat mencapai hasil belajar yang ideal. Apabila guru dalam keadaan siap dan memiliki proficiency (berkemampuan tinggi), harapan terciptanya sumber daya manusia yang berkualitas akan tercapai. Penilaian hasil belajar adalah kegiatan yang bertujuan untuk mengetahui seberapa jauh proses belajar telah berjalan secara afektif. Keefektifan pembelajaran akan tampak pada kemampuan peserta didik dalam mencapai tujuan belajar.

\section{3) Faktor-faktor yang Mempengaruhi Hasil Belajar}

21 Nana Sudjana, Dasar-Dasar Proses Belajar Mengajar, Bandung: Sinar Baru, 1995, cet. III, hlm. 45-46.

22 Nana Sudjana, Penilaian Hasil Proses Belajar Mengajar, Bandung: Remaja Rosdakarya, 1995, hlm. 56-57. 
Ada berbagai faktor yang dapat mempengaruhi proses dan hasil belajar peserta didik di sekolah, secara garis besar faktor tersebut dapat dibagi menjadi dua bagian:

a) Faktor internal (faktor individu peserta didik)

Faktor individu peserta didik yaitu keadaan atau kondisi jasmani dan rohani peserta didik yang meliputi kesehatan mata, telinga, inteligensi, bakat dan minat peserta didik. ${ }^{23}$ Selain itu, faktor fisiologis juga mempengaruhi keberhasilan peserta didik dalam belajar sekurang-kurangnya ada tujuh faktor yang tergolong faktor yaitu inteligensi, minat, bakat, motif, kematangan dan kelelahan. ${ }^{24}$

b) Faktor eksternal (faktor dari luar individu peserta didik)

(1) Lingkungan social

Lingkungan sosial sekolah seperti para guru, para staf administrasi, dan teman-teman se-kelas dapat mempengaruhi semangat belajar seorang peserta didik.

(2) Lingkungan non-sosial

Faktor-faktor yang termasuk lingkungan sosial adalah gedung sekolah dan letaknya, rumah tempat tinggal keluarga peserta didik dan letaknya, alat-alat belajar, keadaan cuaca dan waktu belajar yang digunakan peserta didik. ${ }^{25}$ Lingkungan non-sosial yaitu segala sesuatu yang di luar peserta didik yang merangsang peserta didik untuk mengadakan reaksi atau pembuatan belajar dikelompokkan dalam faktor eksternal, diantaranya faktor keluarga, masyarakat lingkungan, teman sekolah, fasilitas, dan kesulitan bahan ajar.

\section{Metode Demonstrasi}

\section{a. Demonstrasi sebagai Metode Pembelajaran}

23 Muhibbin Syah, Psikologi Pendidikan ... hlm. 132.

24 Slameto, Belajar dan Faktor ... hlm. 55

25 Muhibbin Syah, Psikologi Pendidikan ... hlm. 137-138 
Pengertian metode menurut para ahli, salah satunya adalah menurut Muhibbin Syah dalam bukunya Psikologi Pendidikan dengan Pendekatan Baru, adalah bahwa: Metode secara harfiah berarti (cara). Dalam pemakaian yang umum, metode diartikan sebagai cara melakukan sesuatu kegiatan atau cara-cara melakukan kegiatan dengan menggunakan fakta dan konsep-konsep secara sistematis. ${ }^{26}$ Muzayyin Arifin, pengertian metode adalah cara, bukan langkah atau prosedur. Kata prosedur bersifat teknis administratif atau taksonomi. Seolah-olah mendidik atau mengajar hanya diartikan cara mengandung implikasi mempengaruhi. Maka saling ketergantungan antara pendidik dan anak didik di dalam proses kebersamaan menuju ke arah tujuan tertentu. ${ }^{27}$ Sedang Menurut W.J.S Poerwadarminta berpendapat bahwa, metode adalah (cara) yang telah teratur dan terpikir baik-baik untuk mencapai suatu maksud. 28

Kesimpulan dari pengertian-pengertian di atas yaitu bahwa metode secara umum adalah cara yang tepat dan cepat dalam melakukan sesuatu hal, seperti menyampaikan mata pelajaran. Dalam kamus Inggris-Indonesia, demonstrasi yaitu mempertunjukkan atau mempertontonkan. ${ }^{29}$ Sedangkan pengertian metode demonstrasi menurut Muhibbin Syah adalah metode mengajar dengan cara memperagakan barang, kejadian, aturan dan urutan melakukan kegiatan, baik secara langsung maupun melalui penggunaan media pengajaran yang relevan dengan pokok bahasan atau materi yang sedang disajikan. ${ }^{30}$

Metode demonstrasi adalah metode mengajar yang menggunakan peragaan untuk memperjelas suatu pengertian atau untuk

26 Muhibbin Syah, Psikologi Pendidikan dengan Pendekatan Baru, Bandung: PT. Remaja Rosdakarya, 1995, hlm. 201.

27 Muzayyin Arifin, Filsafat Pendidikan Islam, Jakarta: Buna Aksara, 1987, hlm. 100101.

28 W.J.S Poerwadaminta, Kamus Umum Bahasa Indonesia, Jakarta: Balai Pustaka, 1986, hlm. 649.

29 Jhon M. Echols dan Hassan Shadily, Kamus Inggris-Indonesia, Jakarta: PT. Gramedia, 1984, hlm. 178.

30 Muhibbin Syah, Psikologi Pendidikan ... hlm. 208 
memperlihatkan bagaimana melakukan sesuatu kepada anak didik. Dengan menggunakan metode demonstrasi, guru atau peserta didik memperlihatkan kepada seluruh anggota kelas mengenai suatu proses, misalnya bagaimana cara sholat yang sesuai dengan ajaran Rasulullah SAW. ${ }^{31}$ Menurut Daryanto, metode demonstrasi adalah suatu cara penyajian informasi dalam proses belajar mengajar dengan mempertunjukkan tentang cara melakukan sesuatu disertai penjelasan secara visual dari proses dengan jelas. ${ }^{32}$

Demonstrasi sebagai sebuah metode pembelajaran, secara tidak langsung menempatkan demonstrasi sebagai sebuah instrumen yang menyatu dalam cara pembelajaran peserta didik di dalam kelas maupun di luar kelas. Itu artinya, desain pembelajaran secara tidak langsung akan menggunakan prinsip-prinsip dasar metode demonstrasi sebagai salah satu cara yang tepat untuk menyampaikan pelajaran kepada peserta didik saat melaksanakan proses pembelajaran. Ide ini perlu diketengahkan dalam praksis pembelajaran, karena metode demonstrasi menempatkan seorang guru sebagai pemeraga yang memperagakan langsung suatu hal yang kemudian diikuti oleh peserta didik, sehingga ilmu atau keterampilan yang didemonstrasikan lebih bermakna dalam ingatan masing-masing peserta didik.

Karakter dasar metode demostrasi yang dominan dengan praktik sejelas-jelasnya akan membantu peserta didik dalam memahami praktik sebuah materi pembelajaran secara lebih komprehensif. Pada ruang yang lebih kompromis pelaksanaan pembelajaran dapat mengkombinasikan antara beberapa metode, seperti antara metode ceramah dan metode demonstrasi. Dalam kerangka praksisnya, metode ceramah digunakan untuk memberikan overview materi pada peserta

31 Zakiah Darajat, Metodik Khusus Pengajaran Agama Islam, Jakarta: Bumi Aksara, 1995, hlm. 296.

32 Daryanto, Panduan Proses Pembelajaran Kreatif \& Inofatif Teori dan Praktik dalam Pengembangan Profesionalisme bagi Guru, Jakarta: AV Publisher, 2009, hlm. 403. 
didik, kemudian diikuti dengan pembelajaran menggunakan metode demonstrasi yang bertujuan untuk meriilkan segala materi yang telah tersampaikan pada saat ceramah, walaupun dalam skala mikro.

Dilihat dari perspektif kesejarahan, sebenarnya semenjak zaman Nabi Muhammad SAW, bahkan semenjak awal sejarah kehidupan manusia, penggunaan metode demonstrasi dalam pendidikan sudah ada. Contohnya, pada waktu itu Nabi seorang pendidik yang agung, banyak menggunakan metode demonstrasi perilaku keseharian sebagai seorang muslim, maupun praktek ibadah seperti menjalankan sholat, wudhu, haji dan umrah, dan lain-lain. Semua cara tersebut dipraktikkan dan ditunjukkan oleh Nabi, lalu para umat mengikutinya.

Berdasarkan fakta sejarah tersebut, dapat dijelaskan bahwa dalam beberapa hal terutama materi pembelajaran yang membutuhkan praktik langsung untuk memberikan pemahaman yang komprehensif, sekaligus ketauladanan bagi peserta didik, maka penggunaan metode demonstrasi bisa menjadi salah satu alternatif metode pembelajaran yang koheren dengan kebutuhan pembelajaran tersebut.

\section{b. Langkah-langkah dalam Mengaplikasikan Metode Demonstrasi}

Ada beberapa langkah yang harus dipahami dan digunakan oleh guru, yang terdiri atas perencanaan uji coba dan pelaksanaan oleh guru lalu diikuti oleh peserta didik dan diakhiri dengan adanya evaluasi. Adapun langkah-langkahnya metode demonstrasi sebagai berikut.

1) Merumuskan dengan jelas kecakapan atau keterampilan apa yang diharapkan oleh peserta didik sesudah demonstrasi itu dilakukan.

2) Mempertimbangkan dengan sungguh-sungguh, apakah metode itu wajar dipergunakan, dan apakah ia merupakan metode yang paling efektif untuk mencapai tujuan yang dirumuskan.

3) Jumlah peserta didik memungkinkan untuk diadakan demonstrasi dengan jelas.

4) Mempertimbangkan waktu yang dibutuhkan, apakah tersedia waktu untuk memberi kesempatan kepada peserta didik mengajukan pertanyaan-pertanyaan dan komentar selama dan sesudah demonstrasi.

5) Selama demonstrasi berlangsung, hal-hal yang harus diperhatikan: 
a) Keteranga-keterangan dapat didengar dengan jelas oleh peserta didik.

b) Telah disarankan kepada peserta didik untuk membuat catatancatatan seperlunya.

6) Menetapkan rencana untuk menilai kemajuan peserta didik. Sering perlu diadakan diskusi sesudah demonstrasi berlangsung atau peserta didik mencoba melakukan demonstrasi. ${ }^{33}$

Sedangkan faktor yang perlu diperhatikan dalam melaksanakan metode demonstrasi sebagai berikut:

1) Memberi kesempatan peserta didik untuk mengulangi demonstrasi dengan bantuan penyaji.

2) Peserta lain mengulangi demonstrasi dengan bantuan dari peserta yang sudah paham.

3) Memberi kesempatan pada semua peserta untuk berlatih sendiri. ${ }^{34}$

Adapun tindak lanjut yang perlu digunakan dalam penggunaan metode demonstrasi adalah sebagai berikut:

1) Bersama peserta mengevaluasi pelaksanaan dan hasil peserta.

2) Mengulangi semua langkah demonstrasi, jika perlu.

3) Memberi tugas pada peserta (membuat laporan, dan lain-lain). ${ }^{35}$

Setelah perencanaan-perencanaan tersusun dengan baik, kemudian diadakan uji coba terlebih dahulu agar penerapannya dapat dilaksanakan dengan efektif dan tercapai tujuan belajar mengajar yang telah ditentukan. Dengan mengadakan uji coba, dapat diketahui kekurangan dan kesalahan praktek secara lebih dini dan dapat peluang untuk memperbaiki dan menyempurnakannya. Langkah selanjutnya dari metode ini adalah realisasinya, saat guru memperagakan atau mempertunjukkan suatu proses atau cara melakukan sesuatu sesuai materi yang diajarkan. Kemudian peserta didik diminta untuk mengikuti atau mempertunjukkan kembali apa yang telah dilakukan guru.

Berdasarkan penjelasan di atas, maka unsur-unsur manusiawi peserta didik dapat dilibatkan baik emosi, intelegensi, tingkah laku, serta

33 J.J Hasibuan dan Mujiono, Proses Belajar Mengajar,Bandung: PT. Rosdakarya, 1993, hlm. 31

34 Daryanto, Panduan Proses Pembelajaran ... hlm. 404

35 Daryanto, Panduan Proses Pembelajaran ... hlm. 405. 
indera mereka. Pengalaman langsung itu diperjelas dengan pengertian yang ditangkapnya dan memperkuat daya ingatnya, serta mengetahui apa yang dipelajarinya. Untuk mengetahui sejauh mana hasil yang dicapai dari penggunaan metode demonstrasi tersebut diadakan evaluasi dengan cara meminta peserta didik mendemonstrasikan apa yang telah didemonstrasikan atau dipraktekkan guru. Pada hakikatnya, semua metode itu baik. Tidak ada yang paling baik dan paling efektif, karena hal itu tergantung penempatan dan penggunaan metode terhadap materi yang dibahas. Hal yang paling penting adalah guru mengetahui kelebihan dan kekurangan metode-metode tersebut. Metode demonstrasi ini dapat digunakan apabila bertujuan untuk: memberikan keterampilan guru, memudahkan berbagai jenis penjelasan sebab penggunaan bahasa lebih terbatas, menghindari verbalisme, dan membantu anak dalam memahami dengan jelas jalannya suatu proses dengan penuh perhatian sebab lebih menarik. ${ }^{36}$

\section{c. Kelebihan dan Kekurangan Metode Demonstrasi dalam Proses Belajar Mengajar}

Penggunaan metode demonstrasi dalam proses belajar mengajar memiliki arti penting. Banyak kelebihan atau keuntungan psikologis dan pedagogis yang dapat diraih dengan menggunakan metode demonstrasi, kelebihan tersebut antara lain:

1) Perhatian peserta didik lebih dipusatkan.

2) Proses belajar peserta didik lebih terarah pada materi yang sedang dipelajari.

3) Pengalaman dan kesan sebagai hasil pembelajaran lebih melekat dalam diri peserta didik. ${ }^{37}$

Tidak ada metode yang paling ampuh digunakan dalam pembelajaran, setiap metode pasti memiliki kelemahan atau kekurangan. Kekurangan dalam metode demonstrasi antara lain:

36 Zuhairini, dkk, Metodik Khusus Pendidikan Agama, Surabaya: Usaha Nasional, 1983, hlm. 94-95.

37 Muhibbin Syah, Psikologi Pendidikan ... hlm. 53 
1) Dalam pelaksanaannya, metode demonstrasi memerlukan waktu dan persiapan yang matang, sehingga memerlukan waktu yang banyak.

2) Demonstrasi dalam pelaksanaanyya banyak menyita biaya dan tenaga (jika memakai alat yang mahal)

3) Tidak semua hal dapat didemonstrasikan di dalam kelas.

4) Metode demonstrasi menjadi tidak efektif jika peserta didik tidak turut aktif dan suasana gaduh. 38

\section{Pembelajaran Bidang Studi Al-Qur'an Hadits di MI}

\section{a. Pengertian Pembelajaran Al-Qur'an Hadits}

Al-Qur'an adalah kitab suci Allah yang diturunkan kepada Rasulullah Muhammad SAW. Al-Qur'an merupakan sumber utama ajaran islam yang menjadi petunjuk bagi kehidupan umat manusia, dan rahmat bagi seisi alam semesta. Di dalamnya terkumpul wahyu illahi yang menjadi petunjuk, pedoman, dan pelajaran bagi peserta didik yang mempelajari serta mengamalkannya. Al-Qur'an adalah kitab suci yang terakhir diturunkan Allah. Isinya mencakup segala pokok-pokok syari'at yang terdapat dalam terdapat dalam kitab-kitab suci yang diturunkan sebelumnya. ${ }^{39}$ Karena itu, setiap orang yang mempelajari Al-Qur'an, akan bertambah cinta kepadaNya, cinta untuk membacanya, untuk mempelajarinya, serta untuk mengamalkannya.

Sedangkan Hadits dapat diartikan sebagai pembicaraan, periwayatan, dan pernyataan. Secara khusus, Hadist merupakan penuturan yang disandarkan pada perbuatan dan perkataan Nabi Muhammad SAW sebagaimana yang dituturkan kembali oleh para sahabatnya.40 Mata pelajaran Al-Qur'an Hadits merupakan unsur mata pelajaran Pendidikan Agama Islam pada diberikan kepada peserta didik untuk memahami Al-Qur'an dan Hadits sebagai sumber-sumber ajaran

38 Tayar Yusup dan Syaiful Anwar, Metodologi Pengajaran Agama Islam dan Bahasa Arab, Jakarta: PT. Raja Grafindo Persada, hlm. 53.

39 Departemen Agama RI, Al-Qur'an dan Terjemahnya, Semarang: PT. Karya Toha Putra, t.th., hlm. 102.

40 Cyril Glase, Ensiklopedi Islam (Ringkas), terj. A Mashudi Gufron, Jakarta: Raja Grafindo Persada, 1996, hlm. 11. 
agama Islam dan mengamalkan isi kandungannya sebagai petunjuk dan landasan kehidupan sehari-hari.

\section{b. Tujuan Pembelajaran Al-Qur'an Hadits di MI}

Mata pelajaran Al-Qur'an Hadits di Madrasah Ibtidaiyah adalah salah satu mata pelajaran PAI yang menekankan pada kemampuan membaca dan menulis Al-Qur'an dan Hadits yang benar, hafalan terhadap surat-surat pendek dalam al-qur'an, pengenalan arti atau makna secara sederhana dari surat-surat pendek tersebut, dan haditshadits tentang akhlak terpuji untuk diamalkan dalam kehidupan seharihari melalui keteladanan dan pembiasaan. Hal ini sejalan dengan misi pendidikan dasar adalah untuk:

1) Pengembangan potensi dan kapasitas belajar peserta didik yang menyangkut rasa ingin tahu, percaya diri, keterampilan berkomunikasi, dan kesadaran diri.

2) Pengembangan kemampuan baca tulis-hitung dan bernalar, ketrampilan hidup, dasar-dasar keimanan dan ketakwaan terhadap Tuhan YME.

3) Fondasi bagi pendidikan berikutnya.

Mempertimbangkan psikologis anak, bahwa tahap perkembangan intelektual anak usia 6-11 tahun adalah operasional konkret (Piaget). Peserta didik pada jenjang pendidikan dasar juga merupakan masa social imitation (usia 6-9 tahun) atau masa mencontoh, sehingga diperlukan figur yang dapat memberi contoh dan teladan yang baik dari orangorang sekitarnya (keluarga, guru, dan teman-teman se-permainan), usia 9-12 tahun sebagai masa second star of individualization atau masa individualisasi, dan usia 12-15 tahun merupakan masa social adjustment atau penyesuaian diri secara sosial.

Secara substansial mata pelajaran Al-Qur'an Hadits memiliki kontribusi dalam memberikan motivasi kepada peserta didik untuk mencintai kitab suci, mempelajari dan mempraktekkan ajaran serta nilai-nilai yang terkandung dalam Al-Qur'an Hadits sebagai sumber utama ajaran islam dan sekaligus menjadi pegangan dan pedoman hidup 
dalam kehidupan sehari-hari. ${ }^{41}$ Mata pelajaran Al-Qur'an Hadits di Madrasah Ibtidaiah bertujuan untuk

1) Memberikan kemampuan dasar kepada peserta didik dalam membaca, menulis, membiasakan, dan menggemari membaca AlQur'an dan Hadits.

2) Memberikan pengertian, pemahaman, penghayatan isi kandungan ayat-ayat Al-Qur'an-Hadits melalui keteladanan dan pembiasaan.

3) Membina dan membimbing perilaku peserta didik dengan berpedoman pada isi kandungan ayat Al-Qur'an dan Hadits.

\section{c. Ruang Lingkup Materi Bidang Studi Al-Qur'an Hadits di MI}

Ruang lingkup mata pelajaran Al-Qur'an Hadits di Madrasah Ibtidaiyah meliputi:

1) Pengetahuan dasar membaca dan menulis al-Qur'an yang benar sesuai dengan kaidah ilmu tajwid.

2) Hafalan surat-surat pendek dalam al-Qur'an dan pemahaman sederhana tentang arti dan makna kandungannya serta pengalamannya melalui keteladanan dan pembiasaan dalam kehidupan sehari-hari

3) Pemahaman dan pengalaman melalui keteladanan dan pembiasaan mengenai hadits-hadits yang berkaitan dengan kebersihan, niat, menghormati orang tua, persaudaraan, silaturahmi, takwa, menyayangi anak yatim, salat berjamaah, ciri-ciri orang munafik, dan amal salih. ${ }^{42}$

\section{Pentingnya Metode Demonstrasi dalam Peningkatan Hasil Belajar}

Pembelajaran merupakan proses pendidikan yang mengandung serangkaian perbuatan guru dan peserta didik atas dasar hubungan timbal balik yang berlangsung dalam situasi edukatif untuk mencapai tujuan tertentu. Upaya untuk meningkatkan mutu pendidikan di sekolah harus melalui pembelajaran. Agar tujuan pembelajaran tercapai, guru hendaknya pandai-pandai mengelola kelas dengan memperhatikan efektifitas dan

41 Peraturan Menteri Agama Republik Indonesia No. 2 Tahun 2008, Tentang Kompetensi Lulusan dan Standar Isi Pendidikan Agama Islam dan Bahasa Arab di Madrasah, hlm. 19.

42 Panitia Sertifikasi Guru, "Modul Pendidikan dan Pelatihan Profesi Guru (PLPG) Kelompok Guru MI”, IAIN Walisongo Semarang, hlm. 177. 
efisiensi dari kegiatan belajar mengajar yang telah di rencanakan. Oleh sebab itu, guru harus dapat memilih metode yang tepat untuk peserta didik.

Suatu metode dipilih dan dilaksanakan agar pembelajaran efektif dan efisien. Peneliti memilih metode demonstrasi dalam pembelajaran Al-Qur'an Hadits yang menyenangkan sehingga peserta didik tidak bosan serta pembelajaran dapat lebih efisien. Melalui proses saling bekerja sama yang dikemas dengan cara yang menyenangkan. Dalam metode demonstrasi anak akan lebih bersemangat dalam belajar karena suasana kelas seperti layaknya kegiatan belajar antar teman sehingga dapat mendorong mereka untuk mampu membahas dan memahami pokok bahasan yang sedang mereka pelajari. Demonstrasi dapat meningkatkan proses kerjasama antar peserta didik dalam mencari pemahaman tentang materi yang diajarkan. Peserta didik benar-benar belajar tidak hanya secara individu, tetapi juga secara kelompok agar semua anggota kelompoknya mampu memahami materi pelajaran. Hasilnya, peserta didik saling memberi pemahaman pada sesama teman, sehingga materi pelajaran dapat dipahami oleh peserta didik secara menyeluruh.

Untuk mengetahui hasil proses belajar mengajar, perlu diadakan evaluasi hasil belajar. Evaluasi hasil belajar tidak bertujuan memberi nilai dan label pada anak. Evaluasi bertujuan untuk mengetahui sejauh mana peserta didik belajar dan bagaimana cara belajar yang paling baik diterapkan. $^{43}$ Meningkat atau tidaknya hasil belajar peserta didik, ditunjukkan dengan adanya perbedaan hasil belajar peserta didik pada setiap siklus, sampai akhirnya pada pemberian tes.

Intinya, metode demonstrasi dapat meningkatkan hasil belajar AlQur'an Hadits. Hal ini terbukti dengan adanya peningkatan hasil belajar peserta didik pada tiap siklusnya dan tercapainya indikator keberhasilan yang telah disesuaikan dengan KKM madrasah.

43 Asnawir dan M. Basyiruddin Usman, Media Pembelajaran, Jakarta: Ciputat Pers, 2002, hlm. 130. 


\section{DAFTAR PUSTAKA}

Arifin, Muzayyin, Filsafat Pendidikan Islam, Jakarta: Buna Aksara, 1987.

Arno F. Witting, Psycology of Learning, New York: Mc Graw Hill, 1981.

Asnawir dan M. Basyiruddin Usman, Media Pembelajaran, Jakarta: Ciputat Pers, 2002.

Darajat, Zakiah, Metodik Khusus Pengajaran Agama Islam, Jakarta: Bumi Aksara, 1995.

Daryanto, Panduan Proses Pembelajaran Kreatif \& Inofatif Teori dan Praktik dalam Pengembangan Profesionalisme bagi Guru, Jakarta: AV Publisher, 2009.

Departemen Agama RI, Al-Qur'an dan Terjemahnya, Semarang: PT. Karya Toha Putra, t.th..

Dimyati, Nudjrono, Belajar dan Pembelajaran, Jakarta: Rineka Cipta, 1999.

Djamaroh, Syaiful Bahri, Guru dan Anak Didik dalam Interaksi Edukatif, Jakarta: Rineka Cipta, 2000. , Psikologi Belajar, Jakarta: Rineka Cipta, 2008.

Echols, Jhon M., dan Shadily, Hassan, Kamus Inggris-Indonesia, Jakarta: PT. Gramedia, 1984.

Glase, Cyril, Ensiklopedi Islam (Ringkas), terj. A Mashudi Gufron, Jakarta: Raja Grafindo Persada, 1996.

Hamalik, Oemar, Kurikulum dan Pembelajaran, Jakarta: Bumi Aksara, 2008.

J.J Hasibuan dan Mujiono, Proses Belajar Mengajar, Bandung: PT. Rosdakarya, 1993.

Jihad, Asep, dan Haris, Abdul Evaluasi Pembelajaran, Yogyakarta: Multi Presindo, 2008.

Panitia Sertifikasi Guru, "Modul Pendidikan dan Pelatihan Profesi Guru (PLPG) Kelompok Guru MI”, IAIN Walisongo Semarang.

Peraturan Menteri Agama Republik Indonesia No. 2 Tahun 2008, Tentang Kompetensi Lulusan dan Standar Isi Pendidikan Agama Islam dan Bahasa Arab di Madrasah. 
Sholeh Abdul Azis, At Tarbiyah wa Turuqut At Tadriis, Mesir: Darul Ma'arif, tt.

Slameto, Belajar dan Faktor yang Mempengaruhinya, Jakarta: Rineka Cipta, 1995.

Sudjana, Nana, Dasar-Dasar Proses Belajar Mengajar, Bandung: Sinar Baru, 1995.

Penilaian Hasil Proses Belajar Mengajar, Bandung: Remaja Rosdakarya, 1995.

Sukmadinata, Nana Syaodih, Landasan Psikologi Proses Pendidikan, Bandung: Rosdakarya, 2003.

Suryabrata, Sumadi, Psikologi Pendidikan, Jakarta: PT. Raja Grafindo Persada, 2001.

Syah, Muhibbin, Psikologi Pendidikan dengan Pendekatan Baru, Bandung: PT. Remaja Rosdakarya, 1995.

Triyanto, Model-Model Pembelajaran Inovatif Berorientasi Konstruktivis, Surabaya: Prestasi Pustaka, 2007.

W.J.S Poerwadaminta, Kamus Umum Bahasa Indonesia, Jakarta: Balai Pustaka, 1986.

Yusup, Tayar, dan Anwar, Syaiful, Metodologi Pengajaran Agama Islam dan Bahasa Arab, Jakarta: PT. Raja Grafindo Persada.

Zuhairini, dkk, Metodik Khusus Pendidikan Agama, Surabaya: Usaha Nasional, 1983. 